\title{
Highly siderophile elements behavior in the Paleoarchean Camel Creek komatiites from East Pilbara Terrane, Western Australia
}

\author{
SHUN NAKANO ${ }^{1}$, AKIRA ISHIKAWA ${ }^{1,2}$, YUICHIRO \\ UENO $^{1,2}$ AND TETSUYA YOKOYAMA ${ }^{1}$ \\ ${ }^{1}$ Tokyo Institute of Technology \\ ${ }^{2}$ JAMSTEC \\ Presenting Author: nakano.s.ai@m.titech.ac.jp
}

It was proposed that the abundances of highly siderophile elements (HSEs) in komatiite sources increased during Archean, possibly indicating progressive mixing of the late veneer materials into the deep mantle [1]. However, recent studies argued for an increase in oxygen fugacity of the mantle during the same period [2, 3]. This implies that the lower HSE concentrations in Paleoarchean komatiites may not represent the source characteristics; they rather reflect the lower oxygen fugacity of the Paleoarchean mantle, which limit the release of HSEs into the melt during partial melting. In order to better understand the chemical evolution of Archean mantle, we performed the analyses of major, trace, and HSE abundances coupled with the Re-Os isotope systematics for Paleoarchean Camel Creek komatiites from the East Pilbara Terrane, Western Australia [4]. Our results show that the abundances of V, Sc, Pt, $\mathrm{Pd}$ and Re in the whole-rock of ultramafic cumulates, komatiites and evolved basalts show strong inverse correlation with the $\mathrm{MgO}$ contents, whereas $\mathrm{Cr}, \mathrm{Co}, \mathrm{Ni}, \mathrm{Os}, \mathrm{Ir}$ and $\mathrm{Ru}$ are positively correlated with the $\mathrm{MgO}$ contents. This observation is consistent with their derivation from crystal fractionation of a single common magma. The estimated compositions of the emplaced komatiite lava display $\mathrm{V} / \mathrm{Sc}$ ratio of $4.8-5.3$ and the $\mathrm{Ru}$ abundance of 2.1-4.2 ng/g, both of which are significantly lower than the estimates of post-Archean komatiites/picrites, and are similar to those of archetypal komatiites from the Paleoarchean Barberton Greenstone Belts in Kaapvaal craton. These results suggest that magma sources of Paleoarchean komatiites share common characteristics, although the present study cannot constrain whether secular increase of oxygen fugacity or progressive mixing of late veneer are responsible for the lower HSE abundances in Paleoarchean komatiites. Further systematic study on the behavior of V, Sc and HSEs during partial melting under different oxygen fugacity is required for discriminating the two scenarios.

[1] Maier et al. (2009) Nature 460, 620-623. [2] Nicklas et al. (2018) GCA 222, 447-466. [3] Nicklas et al. (2019) GCA 250, 49-75. [4] Ohta and Maruyama (1998) EOS transection $A G U$ 79, F946. 